\title{
COVID-19 Pandemi Sürecinin Öğrenci Davranışları Üzerine Etkisi
}

\author{
Effect of COVID-19 Pandemic Process on Student Behavior
}

Elif Tarlakazan, Burak Erhan Tarlakazan

\section{ÖZ}

COVID-19 pandemisi tüm dünyayı hiç beklemediği bir anda çeşitli tedbirler almaya yönelten bir süreç olarak gelişmiştir. Bu süreçte insan yaşantısında internet erişimi ve elektronik ortamlar giderek daha fazla yer tutmuştur. Süreç sosyal yaşamın da bu platforma taşınmasına sebep olmuştur. Bu yeni durum neticesinde; iletişim, oyun, alışveriş, eğitim vb. ihtiyaçlar sanal ortamlara taşınmıştır. Araştırma Kastamonu Üniversitesi, Güzel Sanatlar ve Tasarım Fakültesi, Grafik Tasarımı Bölümü öğrencileri özelinde yürütülmüştür. Araştırma COVID-19 pandemisi öncesi ve sürecinde öğrenci davranışlarındaki (yeme-içme, teknoloji kullanımı vb) değişimleri ortaya koymak amacıyla yürütülmüştür. Araştırma verileri; çalışmaya gönüllü olarak katılan, grafik tasarımı bölümüne kayıtlı 93 öğrenciden, bilgisayar destekli çevrimiçi anket yöntemiyle toplanmıştır. Bu kapsamda Kastamonu Üniveritesi Bilimsel Araştırma ve Yayın Etiği Kurulunun 25/03/2021 tarih ve 70 nolu kararınca araştırma yapılması için etik kurul kararı alınmıştır. Araştırma bulgularına göre; COVID-19 sürecinde üniversite öğrencilerinin sosyal medya kullanımlarında bir değişiklik gözlenmezken, arkadaşlarıyla iletişim kurma, çeşitli sosyal aktivitelere katılma oranları düştüğü gözlenmektedir. Ayrıca bu süreçte atıştırmalık ürün tüketimi azalırken ev yemekleri tüketimi artmış, ders çalışma, film izleme, kitap okuma oranında da anlamlı oranda artış gözlenmiştir.

\begin{tabular}{r} 
Yazar Bilgileri \\
Elif Tarlakazan \\
Doç. Dr., Kastamonu \\
Üniversitesi, Kastamonu, \\
Türkiye \\
etarlakazan@kastamonu.edu.tr \\
\hline Burak Erhan Tarlakazan iD \\
Doç. Dr., Kastamonu \\
Üniversitesi, Kastamonu, \\
Türkiye \\
tarlakazan@hotmail.com
\end{tabular}

Makale Bilgileri
Anahtar Kelimeler
COVID-19
Davranış değişikliği
Alışkanlik
Uzaktan erişim
Grafik tasarım
Keywords
COVID-19

Behavior change

Habit

Remote access

Graphic design

Makale Geçmişi

Geliş: 01/06/2020

Düzeltme: $27 / 02 / 2021$

Kabul: 11/03/2021

\footnotetext{
Atıf için: Tarlakazan, E. ve Tarlakazan, B.E. (2021). COVID-19 pandemi sürecinin öğrenci davranışları üzerine etkisi. JRES, 8(1), 52-64. https://doi.org/10.51725/etad.746534

Etik Bildirim: Bu çalışma Kastamonu Üniversitesi Etik Kurulu'nun 25.03 .2021 tarih ve 70 sayılı onayı ile gerçekleştirilmiştir.
} 


\section{Giriş}

Bulaşıcı hastalıkların toplumsal yaşamı tehdidi, tıp ya da bilim tarihiyle sınırlı olmayıp insanlık tarihi boyunca gözlenmiştir. Doğal afetler ya da savaşlar belli coğrafik bölgelerle sınırlı kalırken bulaşıcı hastalıklar sınır dinlemeden her dönemde tüm insanlığı etkilemiş ve insanın olduğu her yerde etkisini göstermiştir. Örneğin, veba salgınları zaman zaman kitlesel ölümlere yol açan pandemiler ile insanlık tarihinde sarsıcı etkiler yaratmıştır.

2019 aralık ayında Çin'in Wuhan kentinde kaynağı tartışmalı bir solunum yolu rahatsızlığı olarak ortaya çıan, mart ayından itibaren tüm Avrupa'yı etkisi altına alan ve 11 Mart'ta Türkiye'de ilk vakanın görülmesiyle hayatımıza giren Covid-19 hızlı yayılımıyla pandemi olarak adlandırılmıştır. Devletin aldığı önlemler arasında ilk sırayı sağlık stratejisi temelli kısıtlamalar almaktadır. Sınırların hem kara hem de hava trafiğine kapatılması önemli bir adımdır. Yurtdışından gelen tüm gruplara 14 gün zorunlu karantina uygulaması başlatılmış üniversiteler ile ilköğretim - lise düzeylerindeki okullar zamanında alınan kararlarla kapatılmıştır. Toplu eylemlerin çoğu (askere uğurlama, cenaze, düğün...vb toplu törenler) engellenmiş ve hastalanmaya en yatkın oldukları için önemli risk grubu olan 65 yaş üstü ve 20 yaş altının sokağa çıkması kısıtlanmıştır. 2020 mart ayında başlayan kısıtlamalar halen benzer uygulamalarla bireysel ve toplumsal sağlığımızı korumak amaçlı uygulanmaktadır.

Sosyoloji (toplumbilim) her zaman bireyin içinde yaşadığı grubu ve grup davranışlarını inceler (Özkalp vd., 2004, s.4). İçinde yaşadığımız dünyada her bir bireyin dünya görüşü, yaşantısı, çevreyi algılama şekli birbirinden farklıdır. Bir başka ifadeyle kişiye özgüdür. Sosyoloji farklı yaşam biçimlerinin görülmesi, algılanması ve birbirinden farklı tutum ve davranışların kavranmasına yardımcı olur. Ve bireyin üyesi olduğu toplumda olan bir değişiklik veya olağanüstü bir durum sosyal yapıya uygun olarak şekillenebilir.

Her bireyin kişilik özellikleri olduğu gibi, (inanç, karakter, mizaç, yetenek... vb.), içinde yaşadıkları toplumlarında inanç ve değer yargısı sistemleri vardır. Toplumun değer yargıları, toplumda oluşan ve ortak kabul gören, düşünce ve kuralların uygulama biçimlerini yansıtan kıstaslardır. Genellikle beğeniye, kabul görmeye ahlak ve inançlara dayanır. Değer yargısı, insan davranışlarının hangilerinin iyi, hangilerinin doğru ve yararlı olduğunu belirler. Bireyin davranışını değerlendirmesinde bir kıstasdır ve bireyin davranışlarına yön veren kurallar ve kanaatler bütünüdür. Tam da bu noktada ülkeyi tehdit eden COVID-19 pandemisi nedeniyle sağlık bakanlığı ve ilgili birimler, öncelikle toplumsal yaşamın düzenini korumak için bazı kısıtlamalara gitmiştir. Kapalı ortamlarda geçirilen izolasyon süreçleri; yerleşik düzenle birlikte; bireysel, toplumsal ve sosyal hayat üzerinde de köklü değişiklikler meydana getirmiştir. Bu kısıtlamalar bireyleri pandemi standartları içinde hareket ve davranışlara alışmaya iten çabalardır. Sonuçlarında da bu kısıtlara uymayan veya uygun hareket etmeyenler çeşitli cezalarla karşı karşıya kalmışlardır.

Alışkanlık kelimesi çoğunlukla "iyi beslenme alışkanlıklarında" olduğu gibi alışılmış bir davranış biçimine veya birinin yerleştirdiği bir eğilime işaret eder. Latince kaynaklı bu kelimenin orijinal anlamı "var olma durumu" veya "koşul"dur. Alışkanlık etimolojisi incelendiğinde kelimenin yanlış ifadesinden doğan bir tanımlamanın "günlük rutin" ifadesi olarak ortaya çıtığı görülmektedir. Alışkanlık kavramı her gün tekrar eden ve düzenli olarak tekrarlanan davranışlar için kullanılan bir terimdir. Ve davranışlarımızın çok büyük bir kısmı alışkanlıklarımızdan oluşur. Bir davranışın alışkanlık olması için sürekli ve tekrar edilmesi gereklidir.

Alışkanlık haline gelen davranışlar beynimizde çok derin bağlantılar oluşturur yani kökleşirler. Aslında alışkanlıkların ne kadar güçlü olduğunu hepimiz kendi yaşamımızda tecrübe etmişizdir. 
Örneğin; derslerde sınıfta genellikle aynı yere oturur, okula giderken aynı güzergâhı kullanır ya da aracımızı evimizin otoparkında aynı yere park ederiz. Hatta böyle durumlarda alışkanlık haline getirdiğimizden farklı şekilde davrandığımızda biraz garip ve rahatsız hissederiz (Neal, Wood ve Quinn, 2006). Ayrıca araştırmalar alışkanlık haline getirdiğimiz davranışı sergilememize sebep olan durum ortadan kalksa bile alışkanlıklarımızı devam ettirebildiğimizi göstermektedir (Sarıgül, 2016).

Bir seçenek sunulduğunda, bireyler genellikle en kolay, en hızlı ve en eğlenceli olan seçeneği seçerler. Bir yaşam tarzı değişikliğinin uygulanması, bir rutinin takip edildiğini ve alışkanlıkların oluştuğunu gösterir (Arlinghaus ve Johnston, 2019).

\section{Davranış Değişikliğine Yönelik Literatür İncelemesi}

Yalman, Özkan ve Kutluca'nın (2013) yaptığı çalışmada; Dicle Üniversitesi Eğitim Fakültesi'nde kayıtlı 220 öğrenciye kitap okuma alışkanlıkları sorulmuştur. Araştırma sonucunda öğrencilerin yarıdan fazlasının kitap okumayı sevdiği, kitapları temin ederken satın aldıkları veya arkadaşlarından ödünç aldıkları ve kitap okuma tercihlerinin macera türünde olduğu tespit edilmiştir.

Ankara Üniversitesi lisans öğrencileri üzerinde yapılan anket çalışmasıyla Odabaş, Odabaş ve Polat (2008), Türkiye'nin genelinde görülen okumama alışkanlığının düzeyini saptamaya çalışmışlardır. Çıkan sonuçlar arasında öğrencilerin yükseköğrenim sürecinde okuma becerilerinin geliştiği ancak yeterli kitap okuma alışkanlığına sahip olmadıkları gözlenmiştir.

Sosyal medya bağımlılı̆̆ı konusunu araştıran Hazar (2011); çalışma grubunun cinsiyet ve sınıf farkları üzerinden tasarladığı araştırmasında, en yoğun kullanılan iletişim aracının internet olduğunu ortaya koymuştur. Cinsiyet faktörüne göre bilişsel, duyuşsal ve davranışsal farklılıkta sosyalleşmeden kaçış ön plandadır. Sınıf bazında ise 1. sınıfların diğer sınıf düzeylerine göre daha az bağımlı olduğu çıkmıştır.

Dijital platformların kullanım amaçlarını belirlemek amacıyla Vural ve Bat'ın (2010) yaptığı araştırma Ege Üniversitesi İletişim Fakültesi'nde okumakta olan öğrencileri kapsamaktadır. Bilgi iletişim ve internet kullanımının sorgulandığı çalışmada, üniversite öğrencilerinin \%100'ünün interneti her gün kullandığı görülmüştür. Bununla beraber birçok öğrencinin zamanının çoğunu sosyal ağlarda geçirmekte olduğu sonucuna ulaşılmıştır.

Tektaş (2014) yaptığı çalışmanın sonuçlarına göre, öğrenciler arasında sosyal medya çok kullanılmaktadır. Çalışma; Marmara Üniversitesi Teknik Bilimler Meslek Yüksekokulu'nda okuyan 221 öğrencinin sosyal medyaya bakış açılarını tespit etmek üzere hazırlanmıştır. Bu amaçla yöneltilen sorulardan elde edilen sonuçlara göre, sosyal medyada kız öğrencilerin erkek öğrencilere oranla daha fazla aktif oldukları görülmüştür.

İnce ve Koçak'ın (2017) yaptığı çalışma, Konya Necmettin Erbakan Üniversitesi'nde öğrenim gören 520 öğrenci üzerinde sosyal medya kullanım alışkanlığını tespit etmek üzere yapılmıştır. Araştırmada ortaya çıan en çarpıcı sonuç sosyal medya kullanım süreleri ile güven ve bağımlılık düzeylerinde artış olmasıdır.

Aydın (2016) tarafından Anadolu Üniversitesi Açıköğretim Fakültesi öğrencilerinin sosyal medya kullanım alışkanlıklarını belirlemeye yönelik yapılan çalı̧̧maya, Nisan-Mayıs 2015 tarihleri arasında 4000'den fazla öğrenci katılmıştır. Katılımcıların sorulara verdikleri yanıtlar yaş ve cinsiyet 
değişkenlerine göre değerlendirilmiştir. Çıkan sonuçlardan büyük ölçüde iletişim kurmak için telefonun tercih edildiği ve arkadaş edinmek için sosyal medya kullanıldığı sonucuna ulaşılmıştır.

\section{Araştırmanın Amacı}

Yeni Koronavirüs Hastalığı (COVID-19) salgını dolayısıyla yükseköğretim kurumlarının eğitim ve öğretim süreçlerinin mümkün olduğunca kesintiye uğramadan sağliklı şekilde yürütülebilmesi için Yükseköğretim Kurulu Eğitim-Öğretim Dairesi Başkanlığının 75850160-199-E.22344 sayı ve 19.03.2020 tarihli kararıyla yüz yüze eğitime ara vermiştir. 2019-2020 eğitim-öğretim döneminin 5. haftası tamamlandığında 13 Mart 2020 tarihinde üniversitelerde eğitim-öğretime ara verildiği duyurulmuş, 1620 Mart 2020 tarihleri arasında YÖK'ün aldığ karara istinaden Kastamonu Üniversitesi'nde de bir hafta süreyle yüzyüze eğitime ara verilmiştir. 23 Mart-22 Mayıs 2020 tarihlerinde de hızlı bir şekilde uzaktan (on-line) eğitim süreci başlamıştır.

Kastamonu yaklaşık 120 bin nüfuslu Batı Karadeniz'de küçük bir Anadolu kentidir. Kastamonu Üniversitesi 2006 yılında temelleri atılmış, Gelişen Genç Üniversite statüsünde olup bünyesinde; 13 fakülte, 3 enstitü, 3 yüksekokul, 13 meslek yüksekokulu ve 23 araştırma ve uygulama merkezi bulunmaktadır. Şehir dışından çok öğrenci kabul eden kentte bir tane AVM, iki tane sinema, üniversite kampüsü çevresinde çok sayıda cafe ve öğrencilerin birlikte vakit geçirebilecekleri öğrenci evi ve yurt bulunmaktadır.

Araştırma; yaşanan pandemi neticesinde üniversite öğrencilerinin alışkanlıklarının devam edip etmediğini, süreçle nasıl başa çıktıklarını ve değişen davranışlarının olup olmadığını belirlemek amacıyla yapılmıştır. Şimdiye kadar bu konuda herhangi bir çalışmaya rastlanmamış olması önem teşkil etmektedir.

Bu amaçla aşağıdaki araştırma sorularına cevap aranmıştır.

- Araştırmaya katılan öğrencilerin COVID-19 pandemi sürecinde alınan önlemlere ilişkin düşünceleri nelerdir?

- COVID-19 öncesi yeme-içme alışkanlıkları nelerdir?

- COVID-19 sırasında yeme-içme alışkanlıkları nelerdir?

- COVID-19 öncesi boş zamanlarını geçirme yöntemleri nasıldır?

- COVID-19 sırasında boş zamanlarını geçirme yöntemleri nasıldır?

\section{Yöntem}

Bu başlık altında araştırmanın modeli, çalışma grubu, veri toplama aracı başlıklarına yer verilmiştir.

\section{Araştırma Modeli}

Güzel Sanatlar ve Tasarım Fakültesi, Grafik Tasarımı Bölümü öğrencilerinin pandemi sürecinde alışkanlıklarının değişip değişmediğini belirlemeyi amaçlayan bu araştırmanın modeli tarama modelidir.

Tarama modeli, bir evren içinden seçilen bir örneklem üzerinde yapılan çalışmalar yoluyla evren genelindeki eğilim, tutum veya görüşlerin nicel olarak betimlenmesini sağlar. Tarama çalışmaları ile olgunun ne olduğu, olabildiğince ve ulaşılabildiğince aynen ortaya konmaya çalışılır (Sönmez ve 
Alacapınar, 2011, s.46-47). Katılımcıların süreçle ilgili görüşlerinin belirlemesi ve bu görüşlerin incelenerek aralarındaki ilişkinin ortaya çıkarılması amaçlanmıştır.

\section{Çalışma Grubu}

Araştırma 2019-2020 eğitim-öğretim yılı bahar yarıyılında Kastamonu Üniversitesi G.S.T. Fakültesi, Grafik Tasarımı Bölümü özelinde ve Covid-19 pandemisi sırasında katılımcıların yazılı onayıyla, ankete katılmayı kabul eden kişilerle yapılmıştır.

Tanımlayıcı nitelikteki bu çalışma nisan-mayıs 2020 tarihleri arasında online anket ile gerçekleştirilmiştir. Araştırmada örneklem hesaplaması yapılmayarak ilgili bölüm öğrencilerinin tamamına (N=120) ulaşılması amaçlanmıştır. Koronavirüs önlemleri kapsamında veriler, yüz yüze görüşme tekniği yerine online veri tabanlı anket yöntemi aracılı̆̆ıyla toplanmıştır. Fakat hastalık, anketi doldurmak istememe gibi nedenlerden dolayı bazı öğrenciler çalışmaya katılım sağlamamıştır. Ankette yer alan tüm soruların yanıtlanmadığı formlar çalışmaya dâhil edilmemiştir. Araştırmaya katılım oranı \%77,5'tir ve gönüllü olarak katılan 93 öğrenci ile etik ilkeleri doğrultusunda araştırma tamamlanmıştır.

Araştırmaya katılarak anketi dolduran Kastamonu Üniversitesi Güzel Sanatlar ve Tasarım Fakültesi Grafik Tasarımı Bölümü öğrencilerinin; \%78,5'i (73) kadın, \%21,5'i (20) erkek öğrencilerden oluşmaktadır. Çalışma grubunun; \%9,7'si (9) birinci sınıf, \%18,3'ü (17) ikinci sınıf, \%31,2'si (29) üçüncü sınıf, \%40,9'u (38) dördüncü sınıf öğrencisinden oluşmaktadır. Ayrıca çalışma grubunun; \%94,6'sının (88) 18-24 yaş, \% 2,2'sinin (2) 25-35 yaş, \%3,2' sinin (3) 36-40 yaş aralığında olduğu görülmüştür. 36-40 yaş aralığında olan 1 öğrencinin 2. üniversitesini okumakta olduğu tespit edilmiştir.

\section{Etik Bildirim}

Bu çalışma Kastamonu Üniversitesi Etik Kurulu'nun 25.03.2021 tarih ve 70 sayılı onayı ile gerçekleştirilmiştir.

\section{Veri Toplama Araçları}

Alan araştırması Kastamonu Üniversitesi Güzel Sanatlar ve Tasarım Fakültesi Grafik Tasarımı Bölümü öğrencileri ile uzaktan eğitim sürecinde uygulanmıştır. Araştırma verilerine uzaktan bilgisayar destekli anket ile ulaşılmıştır. Araştırma için geliştirilen anket verilerini betimlemek için yüzde (\%) ve frekans (f) değerlerinden faydalanılmıştır.

COVID-19 öncesi ve sırasında araştırma katılımcılarının yemek, sosyal çevre, okuma gibi alışkanlıklarındaki değişiklikleri ölçmeyi amaçlayan veriler, araştırmacılar tarafından geliştirilen bir anketle elde edilmiştir. Anketin geliştirilme sürecinde, ilk olarak alanyazın taraması yapılarak benzer nitelikteki ölçme araçları gözden geçirilmiş ve taslak anket oluşturulmuştur. Taslak anket uzmanların görüşlerine sunularak getirilen öneriler ve düzeltmeler doğrultusunda tekrar biçimlendirilmiştir. Anket demografik özellikler ve alışkanlıklar başlıkları altında iki bölümden oluşmaktadır. Beş sorudan oluşan birinci bölüm, öğrencilere ilişkin bireysel bilgilerle ilgilidir. Ankette katılımcıların Covid-19 öncesi ve sırasında yeme-içme alışkanlıkları, sosyal medya kullanımı, eğitim-öğretim faaliyetleri ve sosyal hayatlarıyla ilgili toplam 17 soru bulunmaktadır. Katılımcıların birden fazla seçenek işaretlenebileceği göz önünde bulundurularak hazırlanan çevrimiçi anket çoktan seçmeli sorulardan oluşturulmuştur. 
Anket uygulama sırasında boş bırakılmaması gerekliliği belirtilmiş ve boş olduğu tespit edilen veriler analize dâhil edilmemiştir. Hazırlanan anket formu bu araştırmaya özgüdür ve genellenemez.

\section{Bulgular}

Araştırma kapsamında sorulan anket sorularına verilen yanıtlar tablolaştırılmış ve bu bölümde verilmiştir.

Tablo 1. Koronavirüs/COVID-19 Salgını Karşısında Alınan Önlemleri Onaylama Dağılımı

\begin{tabular}{lccc}
\hline Önlemler & $f$ & Evet (\%) & Hayır (\%) \\
\hline Spor Müsabakalarının İptal Edilmesi & 86 & 92,5 & 7,5 \\
\hline AVM'lerin Kapatılması & 88 & 94,6 & 5,4 \\
\hline Bar/Restoran/Kafelerin Kapatılması & 88 & 94,6 & 5,4 \\
\hline Sinırların Kapatılması & 84 & 90,3 & 1,1 \\
\hline Sinema/Tiyatro Gibi EğlenceYerlerinin Kapatılması & 88 & 94,6 & 5,4 \\
\hline Müze/Galerilerin Kapatılması & 78 & 83,9 & 16,1 \\
\hline Okul/Üniversitelerin Kapatılması & 75 & 80,6 & 19,4 \\
\hline İşyerlerinin Kapatılması & 68 & 73,1 & 26,9 \\
\hline Belli Yaş Guruplarının Sokağa Çıkmasının Kısıtlanması & 68 & 73,1 & 26,9 \\
\hline
\end{tabular}

Ankete katılan öğrencilerin tepkisi, düşünceleri sorulmuş ve ankete katılan her 4 kişiden 3'ünün alınan önlemlerin yerinde olduğunu söylediği belirlenmiştir. AVM'lerin kapanması, Bar/Restoran/Kafelerin kapatılması ve Sinema/Tiyatro gibi sosyal mesafenin korunamayacağı yerlerin kapatılması $(\% 94,6)$ salgına karşı alınan önlemlerde kalabalık alanların kapanmasını, üniversite öğrencilerinin onayladığı görülmektedir.

Tablo 2. Koronavirüs/COVID-19 Salgını Sebebiyle Aşağıdaki Maddelerden Hangilerini Yaptınız?

\begin{tabular}{lccc}
\hline Değişkenler & $f$ & Evet (\%) & Hayır (\%) \\
\hline Kalabalık Yerlerden Uzak Durdum & 92 & 98,9 & 1,1 \\
\hline Toplu Taşımadan Uzak Durdum & 87 & 93,5 & 6,5 \\
\hline Seyahat Planlarımı İptal Ettim & 83 & 89,2 & 10,8 \\
\hline Seyahatlerimin Tarihlerini Değiştirdim & 64 & 68,6 & 31,2 \\
\hline $\begin{array}{l}\text { Partilere ve Davet Edildiğim Sosyal } \\
\text { Etkinliklere Gitmemeye Karar Verdim }\end{array}$ & 84 & 90,3 & 9,7 \\
\hline İhtiyacımdan Fazla Yiyecek/İçecek Stokladım & 26 & 28,0 & 72 \\
\hline $\begin{array}{l}\text { İhtiyacımdan Fazla Temizlik Malzemesi } \\
\text { Stokladım }\end{array}$ & 29 & 31,2 & 68,8 \\
\hline Bar/Restoran/Cafelere Gidişimi Azalttım & 78 & 83,9 & 16,1 \\
\hline
\end{tabular}

Tablo 2 incelendiğinde ise ülkede uygulanan kısıtlamalara maksimum düzeyde uyulduğu ve kısıtlama sürecinde \%98,9 maksimum oranda kalabalık yerlerden uzak durulduğu görülmektedir. Bunu toplu taşımı kullanmamak \% 93,5 ve partilere ve davet edilen sosyal etkinliklere gitmemek \%90,3 takip etmektedir. Araştırma katılımcılarının hem kendi sağlıkları hem de karşıdaki bireylerin sağlığını korumak için alınan önlemlere uyduğu görülmektedir.

Pandemi başından itibaren birçok haber kanalında gündem olan "İhtiyaçtan fazla yiyecek, içeçek ve temizlik maddesi stoğuna" ilişkin öğrencilerin katılım oranının düşük olduğu \%28,0 - \%31,2 tespit edilmiştir. Pandemi sürecinde öğrencilerin ailelerinin yanında olduğu ve ihtiyaçlarının da aileleri tarafından karşılandığı düşünüldüğünde öğrenci ailelerinin stoğa karşı duyarlılık gösterdiği, bilinçli davrandığı çıkarımı yapılabilir. 
Tablo 3. Koronavirüs/COVID-19 Salgınında, Kısıtlamaların Katılımcıları Etkileyip-Etkilememe Durumu

\begin{tabular}{lccc}
\hline Değişkenler & $f$ & Etkiledi (\%) & Etkilemedi(\%) \\
\hline Hafta Sonları Sokağa Çıkma Kısıtlaması & 91 & 97,8 & 2,2 \\
\hline Yüz-Yüze Eğitimin Sonlandırılması & 93 & 100 & 0 \\
\hline Avm'lerin Kapatılması & 11 & 11,8 & 88,2 \\
\hline 20 Yaş Altı ve 65 Yaş Üstüne Sokağa Çıkma & 85 & 91,3 & 8,7 \\
Kısıtlaması & 12 & 12,9 & 87,1 \\
\hline Spor Müsabakalarının Ertelenmesi & 59 & 63,4 & 36,6 \\
\hline Kültür-Sanat Etkinliklerinin Ertelenmesi & 89 & 95,7 & 4,3 \\
\hline Restoran ve Cafelerin Kapatılması & 24 & 25,8 & 74,2 \\
\hline Kuaförlerin Kapatılması & & & \\
\hline
\end{tabular}

Bu salgın sürecinde Tablo 3'e göre yüz yüze eğiminin sonlandırılması (\%100), hafta sonları ve 20 yaş altı ve 65 yaş üstü sokağa çıkma yasağı katılımcıları etkilemiş ve devletin aldığı önlemleri destekleyen sonuçlar gözlenmektedir. Katılımcıların büyük çoğunluğu $(\% 63,4)$ kültür-sanat etkinliklerinin ertelenmesinden etkilenirken en az oranda \%11,8 AVM'lerin kapanması etkilemiştir. Restoran ve cafelerin kapanmasına bakış ise, aslında öğrencilerin en çok vakit geçirdikleri yerlerin restoran ve cafeler olduğu \% 95,7 ve bu mekânların kapatılmasının öğrencileri büyük oranda etkilediği sonucuna ulaşılmıştır.

Tablo 4. Koronavirüs/COVID-19 Salgınında En Çok Vakit Geçirdiğiniz Alanlar Hangileridir?

\begin{tabular}{lcccc}
\hline Değişkenler & \multicolumn{2}{c}{ Öncesinde } & \multicolumn{2}{c}{ Sirasında } \\
\hline Cafe & $f$ & $\mathbf{( \% )}$ & $f$ & $\mathbf{( \% )}$ \\
\hline Eğitim Ortamı & 62 & 66,7 & 0 & 0 \\
\hline AVM & 81 & 87,1 & 0 & 0 \\
\hline Sinema & 34 & 36,6 & 0 & 0 \\
\hline Tiyatro & 29 & 31,2 & 0 & 0 \\
\hline Ev ve Yurt Ortamı & 8 & 8,6 & 0 & 0 \\
\hline Spor Salonları & 72 & 77,4 & 93 & 100 \\
\hline Dijital Platformlar & 20 & 21,5 & 0 & 0 \\
\hline Park & 20 & 21,5 & 65 & 69,9 \\
\hline Market & 24 & 25,8 & 0 & 0 \\
\hline Arkadaş Grupları & 40 & 43 & 2 & 2,1 \\
\hline
\end{tabular}

Araştırma katılımcıları pandemi öncesi \%77,4 ve sırasında \%100 ev ve yurt ortamında vakit geçirmekteyken, öncesinde \%21,5 iken sırasında \%69,9 oranında dijital platformlarda vakit geçirmektedirler. Kısıtlamalara uyularak pandemi sırasında (Mayıs 2020); cafe, park, tiyatro, sinema, spor salonları ve AVM vakit geçirme oranları \%0 olarak belirlenmiştir. Bu durum, AVM'lerin kapatılmış olmasıyla ilgilidir. 
Tablo 5. Koronavirüs/COVID-19 Salgınında Aktivitelerde Değişiklik Durumu

\begin{tabular}{lcccc}
\hline Değişkenler & \multicolumn{2}{c}{ Öncesinde } & \multicolumn{2}{c}{ Sırasında } \\
\hline Video Çekme-Yükleme & $f$ & $\mathbf{( \% )}$ & $f$ & $\mathbf{( \% )}$ \\
\hline Radyo-Müzik Dinleme & 13 & 14 & 58 & 62,4 \\
\hline TV İzleme & 40 & 43 & 34 & 36,6 \\
\hline Haber İzleme & 26 & 28 & 56 & 60,2 \\
\hline Film İzleme & 27 & 29 & 85 & 91,3 \\
\hline Tiyatro İzleme & 54 & 58,1 & 93 & 100 \\
\hline Kitap Okuma & 8 & 8,6 & 5 & 5,4 \\
\hline Gazete Okuma & 52 & 55,9 & 75 & 80,6 \\
\hline Dergi Okuma & 8 & 8,6 & 15 & 16,1 \\
\hline Konsol-Dijital Oyun Oynama & 19 & 20,4 & 21 & 22,6 \\
\hline İnternet Gezintisi & 19 & 20,4 & 28 & 30,1 \\
\hline Arkadaş Buluşması & 58 & 62,4 & 58 & 62,4 \\
\hline Ders Çalışma & 74 & 79,6 & 4 & 4,3 \\
\hline Alişveriş Yapma & 70 & 75,3 & 93 & 100 \\
\hline Sosyal Medya Paylaşımları & 49 & 52,7 & 4 & 4,3 \\
\hline Spor & 42 & 45,2 & 37 & 39,8 \\
\hline Sergi-Müze Ziyaretleri & 27 & 29 & 8 & 8,6 \\
\hline Uzaktan Eğitim Faaliyetlerine & 34 & 36,6 & 3 & 3,2 \\
Katılma & 15 & 16,1 & 90 & 96,8 \\
\hline $\begin{array}{l}\text { Alanımla İlgili Faaliyetlerde } \\
\text { Bulunma(Ders, Proje, Uygulama }\end{array}$ & 57 & 61,3 & 93 & 100 \\
Çalışmaları) & & & & 92,5 \\
\hline Dijital Platformlarda Dizi İzleme & 38 & 40,9 & 86 & \\
\hline & & & & \\
\hline
\end{tabular}

Yapılan aktivitelerin sorgulandığı Tablo 5'te, pandemi öncesinde arkadaş buluşması \%79,6 iken, pandemi sırasında \%4,3'e düşmüştür. Ders çalışma ve alanla ilgili faaliyetlerde bulunma oranında \%100 artış gözlenmektedir. Video çekme-yükleme oranında ciddi bir artış \%62,4, alışveriş yapma oranında ciddi bir azalma \%4,3 dikkat çekmektedir. Spor \%8,6 ve sergi-müze ziyaretleri \%3,2 düşmüştür. Pandemi sırasında TV izleme $\% 60,2$ ve haber izleme oranları $\% 91,3$ pandemi öncesine göre artış göstermektedir. Genç örneklem grubunun yaşananlar hakkında bilgi almak amaçlı tv - haber izleme oranlarında artış olduğu çıkarımı yapılabilir.

Tablo 6. Koronavirüs/COVID-19 Salgınında Atıştırmalık Ürünler Tüketme Durumu

\begin{tabular}{lcccc}
\hline Değişkenler & \multicolumn{2}{c}{ Öncesinde } & \multicolumn{2}{c}{ Sirasında } \\
\hline Cips & $f$ & $\mathbf{( \% )}$ & $f$ & $\mathbf{( \% )}$ \\
\hline Gofret & 52 & 55,9 & 43 & 46,2 \\
\hline Çikolata & 32 & 34,4 & 28 & 30,1 \\
\hline Bisküvi & 63 & 67,7 & 65 & 69,9 \\
\hline Kuruyemiş & 35 & 37,6 & 33 & 35,5 \\
\hline Kraker & 40 & 43 & 48 & 51,6 \\
\hline Şekerleme & 25 & 26,9 & 23 & 24,7 \\
\hline Kurutulmuş meyve & 22 & 23,7 & 27 & 29 \\
\hline Gazlı içecek & 22 & 23,7 & 31 & 33,3 \\
\hline Meyve suyu & 45 & 48,4 & 39 & 41,9 \\
\hline Maden suyu & 49 & 52,7 & 49 & 52,7 \\
\hline
\end{tabular}


Pandemi sürecinde günlük hayatımız çok kısa bir sürede ciddi bir değişime uğramıştır. Tablo 6'ya göre, bu süreçte 18-24 yaş genç nüfusun atıştırmalık alışkanlıklarının değişmediği görülmüştür. Katılımcıların neredeyse yarısı benzer oranlarda çikolata $\% 69,9$, kuruyemiş $\% 51,6$, meyve suyu $\% 52,7$ tüketmektedir. Cips \%46,2 ve gazlı içecek \%52,7 tüketiminde azda olsa düşüş görülmüştür. Üniversite öğrencilerinin cips ve gazlı içeçek ürünlerindeki tüketimlerinde tespit edilen azalma, öğrencilerin arkadaş ortamından uzak olmalarıyla ilişkilendirilebilir.

Tablo 7. Koronavirüs/COVID-19 Salgınında Gıda Tüketim Durumu

\begin{tabular}{lcccc}
\hline Değişkenler & \multicolumn{2}{c}{ Öncesinde } & \multicolumn{2}{c}{ Sırasında } \\
\hline Pizza & $f$ & $\mathbf{( \% )}$ & $f$ & $\mathbf{( \% )}$ \\
\hline Hamburger & 34 & 36,6 & 12 & 12,9 \\
\hline Ev yemeği & 53 & 57 & 6 & 6,5 \\
\hline Hazır çorba & 58 & 62,4 & 88 & 94,6 \\
\hline Sandviç & 36 & 38,7 & 13 & 14 \\
\hline Makarna & 31 & 33,3 & 13 & 14 \\
\hline Noodle & 50 & 53,8 & 50 & 53,8 \\
\hline Misır gevrekleri & 38 & 40,9 & 12 & 2,9 \\
\hline Poğaça-çörek & 19 & 20,4 & 13 & 14 \\
\hline Simit & 47 & 50,5 & 31 & 33,3 \\
\hline Kek & 46 & 49,5 & 10 & 0,8 \\
\hline Patates kızartması & 26 & 28 & 44 & 47,3 \\
\hline Meyve & 54 & 8,1 & 47 & 50,5 \\
\hline & 47 & 50,5 & 66 & 71 \\
\hline
\end{tabular}

Tablo 7.de Covid-19 öncesi ve sırasında katılımcıların gıda tüketimleri yeme oranları arttı mı azaldı mı şeklinde sorulmuş ve ev yemeği 94,6 tüketim oranı pandemi sırasında ciddi bir artış göstermektedir. Pizza \%12,9, hazır çorba \%14, sandviç \%14, noddle \%12,9, mısır gevreği \%14, simit $\% 10,8$, patates kızartması \%50,5 tüketimi azalırken, makarna tüketimi \%53,8 aynı kalırken, hamburger tüketimi \%6,5 azalmıştır. Tablo 6da olduğu gibi arkadaş ortamından uzakta, aile evinde olmanın etkisiyle hazır gıdaların tüketimi azalmışır.

Tablo 8. Koronavirüs/COVID-19 Salgını Öncesi ve Sırasında Cihaz Kullanma Durumu

\begin{tabular}{lcccc}
\hline Değişkenler & \multicolumn{2}{c}{ Öncesinde } & \multicolumn{2}{c}{ Sirasinda } \\
\hline Dizüstü Bilgisayar (Laptop) & $f$ & $\mathbf{( \% )}$ & $f$ & $\mathbf{( \% )}$ \\
\hline Masaüstü bilgisayar & 80 & 86 & 83 & 89,2 \\
\hline Oyun konsolları & 3 & 3,2 & 6 & 6,5 \\
\hline Bluetooth hoparlör & 4 & 4,3 & 10 & 10,8 \\
\hline Müzik çalar & 18 & 19,4 & 17 & 18,3 \\
\hline Akıllı TV & 22 & 23,7 & 24 & 25,8 \\
\hline Cep telefonu & 10 & 10,8 & 31 & 33,3 \\
\hline Akıllı saat & 87 & 93,5 & 88 & 94,6 \\
\hline Tablet & 4 & 4,3 & 2 & 2,2 \\
\hline
\end{tabular}

Araştırmaya konu olan grup tasarım fakültesi öğrencileri olmaları nedeniyle bilgisayar kullanmaktadırlar. Dizüstü bilgisayar (laptop) kullanım oranı \%89,2 pandemi öncesinde ve sonrasında hemen hemen aynıdır. Cep telefonu \%94,6 kullanım oranıdır. Diğer cihazların kullanım oranlarında kayda değer bir değişiklik gözlenmemiştir. 
Tablo 9. Koronavirüs/COVID-19 Salgınında Kültür Sanat Etkinliklerinin İzlenme Durumu

\begin{tabular}{lcc}
\hline Değişkenler & $f$ & $\mathbf{( \% )}$ \\
\hline Salgın Geçene Kadar Ertelenmeli & 71 & 76,3 \\
\hline Sosyal Mesafe Kuralıyla Yeniden Aynı Ortamında Başlatılmalı & 14 & 15,1 \\
\hline Uzaktan Erişimle Etkinlikler İzlenebilmeli & 83 & 89,2 \\
\hline Sanal Sergiler Düzenlenmeli & 93 & 100 \\
\hline Müzeler Sanal Ortamlarda Ziyaret Edilebilmeli & 85 & 91,4 \\
\hline
\end{tabular}

Pandemi sürecinde ertelenen kültür-sanat etkinlikleriyle ilgili izlenebilecek yollar için katılımcıların düşünceleri tablo 9'da verilmiştir. Salgın geçene kadar bu tür etkinliklerin ertelenmesi \%76,3 gerektiğini düşünmektedirler. Ayrıca sanal sergi etkinliklerinin \%100 ve müzelerin sanal ortamda ziyaret edilebilmesinin \%91,4 olumlu motivasyon sağladığı gözlenmektedir.

\section{Tartışma, Sonuç ve Öneriler}

İnsanoğlu yaşadığı süreçte meydana gelen olaylar ve değişiklikler karşısında farklı tepkiler geliştirebilme, yeniliklere ve oluşan yeni koşullara uyum sağlayabilme niteliklerine sahip olarak gelişim göstermektedir. Gerek bölgesel gerekse küresel ölçekte yaşanan; savaşlar, çevre felaketleri, doğal afetler, salgın hastalıklar vb. oluşumlar, insan hayatındaki çözüm geliştirilen durumlardır. Bu anlamda küresel ölçekli bir sorun olarak ortaya çıkan, dünyada ve ülkemizde bir süredir etkili olan Covid-19 pandemisi sosyal, kültürel, ekonomik ve eğitim gibi alanlarda pek çok değişikliği beraberinde getirmiştir. İnsanlık, gelişen bu yeni durumla beraber bir anda farklı yaşam koşullarıyla yüz yüze kalmış bulunmaktadır.

Maske kullanımı ve sosyal mesafe kavramı yaşamın bir gerekliliği olmuş, temasın yerini mesafeli selamlaşma almıştır. Gelişen süreç toplumun her kesiminden, her yaş grubunda bireyi farklı biçimlerde etkilemiştir. Örneğin 20 yaş altı ve 65 yaş üstü sokağa çıkma kısıtlaması ile pandemi bulaş riskinin aza indirilmesi amaçlanmış toplum sağlığını korumak hedeflenmiştir. 21 Mart 2020 tarihinden itibaren ikametlerinden dışarı çıkmaları, açık alanlarda, parklarda dolaşmaları ve toplu taşıma araçlarını ile seyahat etmelerinin sınırlandırılarak sokağa çıkmaları sınırlandırılmıştır. Bunu yanında evlerde kalarak sosyal izolasyonun sağlanması iletişimin sosyal medya üzerinden devam etmesine neden olmuştur.

Bu çalışmada; pandemi öncesi ve sırasında, genç nüfusun sürece yönelik düşünceleri ve alışkanlıkları belirlenmeye çalışılmıştır. Alanyazında genç nüfusun okuma alışkanlıkları ve sosyal medya kullanımı gibi konularda çeşitli araştırmalar bulunmaktadır. Ancak gelişen salgın nedeniyle yaşanan süreçle ilişkili ne gibi farklılıklar geliştirildiği konusunun değerlendirilmesi, bu çalışmanın amacını oluşturmaktadır.

Araştırmada elde edilen veriler 1şığında; üniversite öğrencilerinin devletin aldığı kısıtlama kararlarını olumlu bakış açısıyla destekledikleri gözlenirken, sosyal, kültürel, ekonomik faaliyetleri sekteye uğratmayacak şekilde sürekliliğ̈inin de gerektiği sonucu ortaya çıkmıştır. Fox (2004) tarafından yapılan araştırmada da benzer biçimde SARS epidemisinde öğrencilerin, sınıf dışı bir ortamda çevrimiçi öğrenme etkinliklerini tamamlama ve hayata geçirmekte sıkıntı yaşadıkları ortaya çıkmıştır. Dünya çapında yayılmayı kontrol altına almak amacıyla pek çok ülke tıpkı bizim gibi, eğitim kurumlarını geçici olarak kapatılmıştır. Ülke çapındaki bu kapanışlar, dünya genelindeki milyonları etkileyen 
yerelleştirilmiş kapatmalar uygulanmış (UNESCO, 2020), halende ülkemizde eğitim öğretim faaliyetleri uzaktan eğtim, online eğitim, seyreltilmiş eğitim v.b. gibi özelinde devam etmektedir.

Salgın sürecinde katılımcılarının günlük sosyal medya kullanım sürelerinde herhangi bir fark görülmezken hepsinin akıllı telefon ve dizüstü bilgisayar kullanıcısı olduğu saptanmıştır. Sosyal medyada geçirilen zaman ve paylaşımları konusunda salgının önemli bir değişkenlik yaratmadığı belirlenmiştir. Aynı zamanda elektronik iletişim cihaz kullanımı konusunda bir farklılık ortaya çıkmamıştır. İnsanlar bilgi ihtiyaçlarını salgın döneminde geleneksel medyada büyük ölçüde televizyondan karşılamıştır. Diğer yandan dijital iletişim araçları da bilgi edinmede önemini korumuş, insanların karantina uygulamalarında vakit geçirmek için de başvurduğu önemli bir araç olarak öne çıkmıştır (Nielsen Medya Tüketim Raporu, 2020).

Araştırmada elde edilen bir diğer sonuç ise; atıştırmalık ürün tüketim alışkanlıklarının değişmediği, yeme içme ürünlerinin tüketiminde ise alışkanlıklarının değiştiği yönündedir. Hamburger, sandviç, pizza, poğaça vb. hazır ve hızlı yemek ürünlerinin tüketiminin azaldığı buna karşılık ev yemeği yeme oranında süreçle alakalı gözle görülür bir artış görülmüştür. Bununla beraber meyve tüketiminin de arttığı gözlenmiştir. Süreçte öğrencilerin aile ortamlarında olmalarının da bu davranış değişikliğinde bir etkisi olduğu söylenebilir. Salgın süreci boyunca sağlıklı bireylerde de özellikle bağışıklık sisteminin desteklenmesi için yeterli ve dengeli beslenme sağlanmalıdır (Muslu ve Ersü, 2020). Ayrıca (Dilber ve Dilber, 2020) araştırmasına göre salgın sürecinde hem evde kalıyor olmak hem de sağlığa gösterilen ekstra özenin, beslenme alışkanlıklarına da yansıdığını söyleyebiliriz bulgusu, bu çalışma bulgularını destekler niteliktedir.

Okul ve üniversitelerin kapatılması ve yüz yüze eğitimin sonlandırılması katılımcıları önemli ölçüde etkilemiştir. Gonzales vd. tarafından (2020) yapılan araştırmada COVID-19 dolayısıyla okulların kapanmasının öğrencilerin öğrenme stratejilerini daha etkin kullanmaya başladıkları ve bunu bir alışkanlık haline getirerek verimliliklerini arttırdıkları sonucuna ulaşılmıştır.

Katılımcı öğrencilerin kültür sanat etkinliklerini kısmen de olsa uzaktan erişim imkânlarıyla sürdürmesi, sanal sergi ve müze ziyaretlerinin bu süreçte yapılabilmesi anlamında da olumlu görüşleri bulunmaktadır. Eğitim alanlarından, sanat çevresinden uzaklaşmadıklarını, çevrimiçi sergi ve müze ziyaretlerinin olduğunu gösterir bulgu sonuçları elde edilmiştir.

Sonuç olarak, Kastamonu Üniversitesi Güzel Sanatlar ve Tasarım Fakültesi Grafik Tasarımı Bölümü öğrencilerinin katılımıyla yapılan bu çalışmada, salgın sürecinde özellikle yeme-içme alışkanlıklarında, sosyal, kültürel ve sanatsal hayat ve iletişim ortamlarında pandemiye uygun şekillenmeler olduğu görülmektedir.

$\mathrm{Bu}$ sonuçtan hareketle benzer amaçla farklı örneklem grupları üzerinde yürütülecek araştırmalarla literatür genişliği sağlanabilir.

Çalışmanın aynı zamanda farklı araştırmalarla karşılaştırma yapma olanağı getirme bakımından alanyazına katkı sağlaması umulmaktadır.

\section{Kaynaklar}

Arlinghaus, K.R. ve Johnston, C.A. (2019). The importance of creating habits and routine. American Journal of Lifestyle Medicine, 13(2), 142-144.

Aydın, E.İ. (2016). Üniversite öğrencilerinin sosyal medya kullanımları üzerine bir araştırma: Anadolu Üniversitesi örneği. Selçuk Üniversitesi Sosyal Bilimler Enstitüsü Dergisi, 35, 373-386. 
Dilber, A. ve Dilber, F. (2020). Koronavirüs (COVID-19) salgınının bireylerin beslenme alışkanlıkları üzerindeki etkisi: Karaman ili örneği. Journal of Tourism and Gastronomy Studies, 8(3), 2144-2162.

Fox, R. (2004). SARS epidemic: Teachers' experiences using ICTs. R. Atkinson, C. McBeath, D. JonasDwyer ve R. Phillips (Ed.), Beyond the comfort zone: Proceedings of the 21st ASCILITE Conference içinde (s.319-327). Perth. http://www.ascilite.org.au/conferences/perth04/procs/fox.html sayfasından erişilmiştir.

Gonzalez, T., de la Rubia, M.A., Hincz, K.P., Comas-Lopez, M., Subirats, L. ve Sacha, G.M. (2020). Influence of COVID-19 confinement in students' performance in higher education. https://www.ncbi.nlm.nih.gov/pmc/articles/PMC7546684/pdf/pone.0239490.pdf sayfasindan erişilmiştir.

Hazar, M. (2011). Sosyal medya bağımlılı̆̆1-bir alan çalışması. Gazi Üniversitesi İletişim Fakültesi İletişim Kuram ve Araştırma Dergisi, (32), 151-175.

İnce, M. ve Koçak, M.C. (2017). Üniversite öğrencilerinin sosyal medya kullanım alışkanlıkları: Necmettin Erbakan Üniversitesi örneği. Karabük Üniversitesi Sosyal Bilimler Enstitüsü Dergisi, $7(2), 736-749$.

Muslu, M. ve Ersü, D. Ö. (2020) Yeni Koronavirüs (SARS-CoV-2/COVID-19) pandemisi sırasında beslenme tedavisi ve önemi. Beslenme Diyetetik Dergisi, (Erken Görünüm), 1-10.

Neal, D.T., Wood, W. ve Quinn, J.M. (2006). Habits-a repeat performance. Current Directions in Psychological Science, 15(4), 198-202.

Nielsen Medya Tüketim Raporu. (2020). https://www.nielsen.com/us/en/insights/article/2020/covid-19key-questions-allmarketers-should-be-asking/ sayfasından erişilmiştir.

Odabaş, H., Odabaş, Z.Y. ve Polat, C. (2008). Üniversite öğrencilerinin okuma alışkanlığg: Ankara Üniversitesi örneği. Bilgi Dünyası, 9(2), 431-465.

Özkalp, E., Arıcı, H., Bayraktar, R., Aydın, O., Erkal, B. ve Uzunöz, A. (2004). Davranış bilimlerine giriş. Eskişehir: Anadolu Üniversitesi.

Sarıgül, T. (2016). Alışkanlıklarımızı terk etmek neden çok zor!. http://bilimgenc.tubitak.gov.tr/makale sayfasından erişilmiştir.

Sönmez, V. ve Alacapinar, F. G. (2011). Örneklendirilmiş bilimsel araştırma yöntemleri. Ankara: Anı.

Tektaş, N. (2014). Üniversite öğrencilerinin sosyal ağları kullanımlarına yönelik bir araştırma. Journal of History School (JOHS), 7(17), 851-870.

UNESCO (2020). Education: From disruption recovery. https://en.unesco.org/covid19/educationresponse sayfasından erişilmiştir.

Vural, Z.B.A. ve Bat, M. (2010). Yeni bir iletişim ortamı olarak sosyal medya: Ege Üniversitesi İletişim Fakültesine yönelik bir araştırma. Journal of Yaşar University, 20(5), 3348-3382.

Yalman, M., Özkan, E. ve Kutluca, T. (2013). Eğitim fakültesi öğrencilerinin kitap okuma alışkanlıkları üzerine betimsel bir araştırma: Dicle Üniversitesi örneği. Bilgi Dünyası, 14(2), 291-305.

\section{Yazarların Katkı Oranı Beyanı}

Yazarlar araştırma sürecinde eşit oranda katkı sağlamıştır. 


\section{Destek ve Teşekkür Beyanı}

$\mathrm{Bu}$ araştırmada herhangi bir kurum, kuruluş ya da kişiden destek alınmamıştır.

\section{Çatışma Beyanı}

Araştırmacının araştırma ile ilgili diğer kişi ve kurumlarla herhangi bir kişisel ve finansal çıkar çatışması yoktur.

\section{Etik Bildirim}

Bu çalışma Kastamonu Üniversitesi Etik Kurulu'nun 25.03.2021 tarih ve 70 sayılı onayı ile gerçekleştirilmiştir. 